Academic Platform Journal of Engineering and Science

\title{
Gasification of Forest Residues for Sustainable Development in the Mediterranean Region of Turkey
}

\author{
*12Zuhal Akyürek, ${ }^{2}$ Afşin Güngör \\ ${ }^{1}$ Burdur Mehmet Akif Ersoy University, Faculty of Engineering and Architecture, Department of Energy Systems Engineering, \\ Istiklal Campus,15030, Burdur, Turkey, drzuhalakyurek@gmail.com, iD \\ ${ }^{2}$ Akdeniz University, Faculty of Engineering, Department of Mechanical Engineering, 07070, Antalya, Turkey, \\ afsingungor@hotmail.com,
}

Research Paper

Arrival Date: 24.07.2020

Accepted Date: 03.08.2021

\begin{abstract}
In this study, the energy generation potential of forest residues in the Mediterranean Region of Turkey are determined by using different gasifier technologies. Gasification is one of the conventional waste to energy conversion technologies for energy production. Syngas, the end product of gasification process, is generally used in internal combustion engines, turbines and boilers as a renewable fuel. Energy potential of forest residues in Mediterranean Region of Turkey was estimated in up-draft fixed bed gasifier, down-draft fixed bed gasifier and circulating fluidized bed gasification systems. The theoretical results revealed that, among the alternatives, down-draft gasifier has shown the highest annual energy production potential of $1125 \mathrm{GWh}$. The results revealed that forest residues can be utilized as significant renewable energy source in Turkey.
\end{abstract}

Keywords: Gasification; Forest Residues; Renewable Energy; Waste Management; Turkey

\section{INTRODUCTION}

Energy is the key driver of sustainable development. The rapid growth in population, technology and industrial development have triggered the global energy demand in the past decades. This continuously increasing energy demand have resulted in environmental pollution due to emission of greenhouse gases from fossil resources [1]. Renewable energy is a vital instrument to mitigate climate change $[2,3]$. Biomass is considered as one of the viable options for renewable energy production to reduce the adverse effects of fossil fuel combustion and for overcoming the severe environmental damage [3-6].

Biomass is a readily available, affordable and clean energy supply that can be derived from a variety of waste materials including forestry residues, agricultural crops, agroindustrial and Municipal Solid Waste (MSW) with different moisture content and chemical composition [7]. Energy from biomass has a major advantage of being stored and transformed into heat and electricity, unlike the other renewable sources. Utilization of biomass provides recovering energy from waste materials and protecting environment from anthropogenic emissions [8]. In the view of these issues, valorization of bio-waste by means of renewable energy production gains more importance for a sustainable environment.
Combustion, pyrolysis and gasification are three main thermochemical conversion technologies for production of energy from solid fuels. The gasification process plays an important role in terms of the opportunity to convert waste into a clean and usable form of energy under thermal conditions. In gasification, thermal oxidation of biomass is carried out in a medium with lower amount of oxygen than what is required for stoichiometric combustion, in the temperature range of $800-1000{ }^{\circ} \mathrm{C}$ to produce highly flammable gas composed mainly of methane, hydrogen, oxygen, carbon dioxide and nitrogen [9-13]. Compared to other conventional technologies such as combustion and pyrolysis, gasification can provide greater energy recovery, heat capacity and better conversion efficiency, etc. [14].

Operational parameters and biomass characteristics such as moisture content of fuel, gasifying agent, equivalence ratio, gasifier temperature, particle size and shape of biomass, etc. have strong influence on the gasification efficiency [15]. Air, oxygen and/or steam are used as gasifying agents in gasification process. Several studies have carried out on biomass gasification with different gasifying agents, temperatures and gasifiers [16-19]. Air is more widely used as gasifying agent compared to other alternative agents such as steam, air/steam, oxygen hence due to its economical and operationally advantageous feature [20]. Syngas quality depends on its heating value and tar content. Higher the 
heating value and lower the tar content results in higher quality [21].

Gasification is a practical route for energy production from woody fuels. Hanaoka et al. [22] studied the effect of woody biomass components on air-steam gasification using the downdraft fixed-bed gasifier and suggest that data obtained in gasification process could possibly be used to predict the composition of product gas generated in air-steam gasification of woody biomass. Kim et al. [23] investigated air-blown gasification of woody biomass in a pilot-scale bubbling fluidized bed gasifier. The composition of the syngas was significantly affected by equivalence ratio. They obtained syngas with adequate heating value for power generation using a syngas engine. Safarian et al. [24] developed an equilibrium simulation model was to evaluate the performance of 28 wood and woody biomass gasification in a downdraft gasifier.

High amount of forestry residues in Turkey signify their availability for energy production. In this study, gasification energy potential of forestry residue inventory in Mediterranean Region has been evaluated with different types of gasifiers by using the previously published syngas composition data $[15,19]$.

\section{MATERIALS AND METHODS}

The Mediterranean Region occupies the southern coast of Turkey, including Antalya, Burdur, Isparta, Mersin, Adana, Hatay, Osmaniye and Kahramanmaraş provinces. The climate of the region is characterized by rainy and cool winters, and dry and hot summers at the coastal parts and cold, snowy winters and dry and hot summers in the interior parts. The region has total land area of $8,943,734$ ha where forestry land occupies 4,181,174 ha [25]. The distribution of forestry areas in the region is demonstrated in Figure 1.

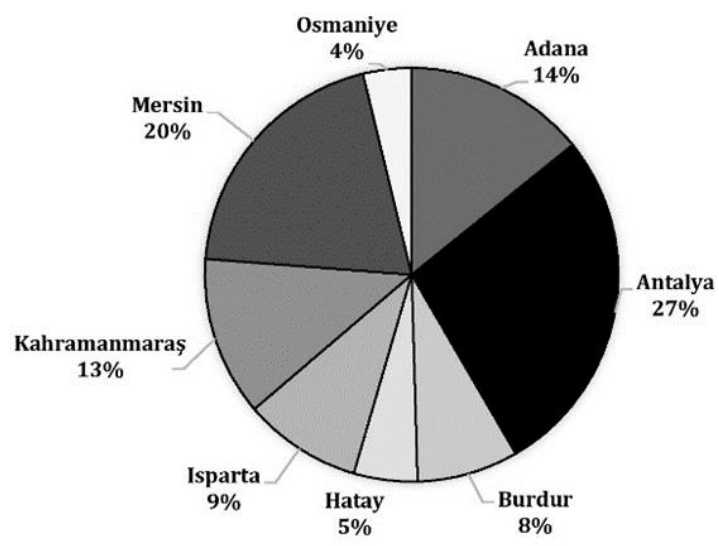

Figure 1. Distribution of total forestry areas in the Mediterranean Region

Forest residues generally consist of logging residues and dead wood. High availability of forestry residues in the
Region offers great potential for renewable energy production. Forestry residue production rates in the Region are shown in Table 1. The data has collected from Biomass Map of Turkey (BEPA) [21].

Table 1. Forestry residue amount and their tons of oil equivalence in the Mediterranean Region.

\begin{tabular}{|c|c|c|}
\hline $\begin{array}{c}\text { Forest Managing } \\
\text { Directorate }\end{array}$ & $\begin{array}{c}\text { Waste } \\
\text { Potential } \\
\text { (ton/year) }\end{array}$ & $\begin{array}{c}\text { Energy } \\
\text { Equivalence } \\
\text { (TOE) }\end{array}$ \\
\hline Adana & $315,200.00$ & 175,995 \\
\hline Antalya & $88,196.40$ & 49,370 \\
\hline Isparta & 2,720 & 1,508 \\
\hline Mersin & $98,520.00$ & 54,349 \\
\hline Kahramanmaraş & $15,192.40$ & 8,421 \\
\hline Total & $\mathbf{5 1 9 , 8 2 8 . 8}$ & $\mathbf{2 8 9 , 6 4 3}$ \\
\hline
\end{tabular}

Biomass gasifiers convert organic solid materials into a gaseous fuel. The specific gas production rate is calculated from the ratio of the syngas flow-rate (in $\mathrm{Nm}^{3} / \mathrm{h}$ ) and the biomass fed to the gasifier (in $\mathrm{kg} / \mathrm{h}$ ) [15]:

$$
P R_{\text {Syngas }}\left(\frac{\mathrm{Nm}^{3}}{\mathrm{~kg}}\right)=\frac{Q_{\text {Syngas }}}{M_{\text {Biomass }}}
$$

The energy value of the syngas can be expressed:

$$
E_{\text {Syngas }}\left(\frac{M J}{N m^{3}}\right)=\frac{Q_{\text {Syngas } L H V_{\text {Syngas }}}}{M_{\text {Biomass }} L H V_{\text {Biomass }}}
$$

Different types of gasifiers have been developed for partial oxidation of the solid waste such as fixed bed downdraft, fixed bed updraft, fluidized bed. Schematic description of the gasifier types used in this study is demonstrated in Figure 2.

As can be seen from the figure, in the updraft gasifiers, the gasifying agents such as air, oxygen and steam enter the system from the bottom part of the gasifier and leaves from the top. This configuration provides counter current interaction of biomass and combustible gases. In updraft gasifier high thermal efficiency can be achieved however, syngas can be contaminated with tar particles when leaving the system, which restricts its application in turbine and engines [26]. Solid fuel enters the system from the top of gasifier and move toward the bottom where it gets oxidized and generate flue gases. In downdraft gasifiers co-current flow of solid fuel and gasifying agent enters from the top of the gasifier and move in downward direction which reduces the tar contamination of syngas. Fluidized bed gasifiers have highly fuel flexible configuration. In circulating fluidized beds, biomass circulates within the gasifier and the cyclone separator. In Table 2, typical syngas compositions for different air-gasifiers using wood biomass are presented. 

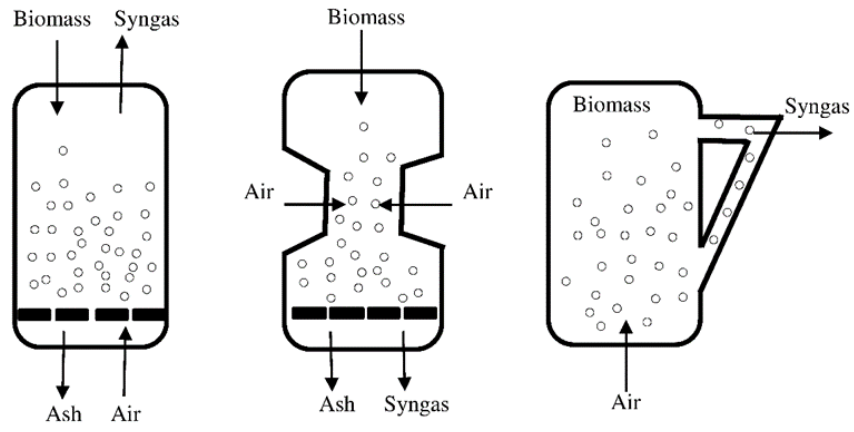

Figure 2. Different gasifier configurations (a) updraft, (b) downdraft, (c) circulating fluidized bed (CFB) [7].

Table 2. Syngas composition from experimental results of woody biomass gasification using different types of gasifiers $[15,19]$

\begin{tabular}{|c|c|c|c|c|c|}
\hline $\begin{array}{c}\text { Gasifier } \\
\text { Type }\end{array}$ & \multicolumn{5}{|c|}{ Gas composition (\% vol, dry basis) } \\
\hline & $\mathbf{H}_{\mathbf{2}}$ & $\mathbf{C O}$ & $\mathbf{C O}_{\mathbf{2}}$ & $\mathbf{C H}_{\mathbf{4}}$ & $\mathbf{N}_{\mathbf{2}}$ \\
\hline Updraft & 11 & 24 & 9 & 3 & 53 \\
\hline Downdraft & 17 & 21 & 13 & 1 & 48 \\
\hline CFB & 14.1 & 18.7 & 14.7 & 3.5 & 47.7 \\
\hline
\end{tabular}

\section{RESULTS AND DISCUSSION}

Biomass gasification systems are used to convert solid biomass into producer gas, which has high calorific value. The efficiency of gasifiers and the composition of the syngas depends on many factors such as operating parameters, gasifying agents and gasifier types. In this study the energy content of the produced syngas from forestry residues are calculated by using the results of experimental studies that are performed in different gasifier configurations such as updraft fixed bed, downdraft fixed bed and circulating fluidized bed gasifiers [7]. The estimated syngas composition of the biomass residues is shown in Figure 3.

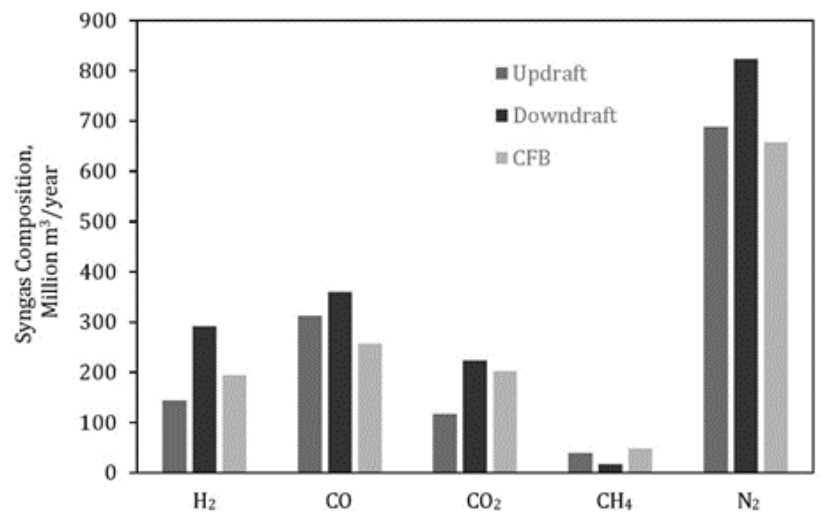

Figure 3. Production rate of syngas components from updraft, downdraft and CFB systems

As can be seen from the figure downdraft gasifier has shown to have higher hydrogen, carbon monoxide, carbon dioxide and nitrogen emission indicating higher energy production performance compared to updraft and circulating fluidized bed systems.

Energy generation potential of forestry residues is illustrated in Figure 4.

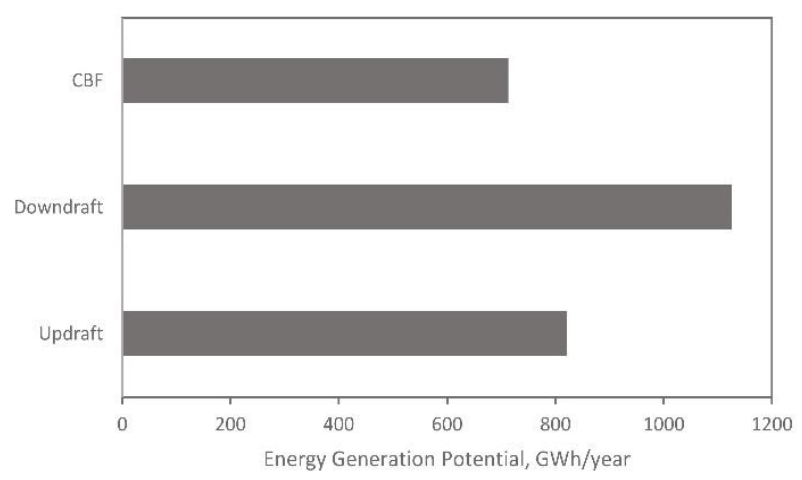

Figure 4. Energy potential of forest residues in the Mediterranean Region from updraft, downdraft and CFB systems.

Annual energy generational potential from downdraft gasifier system is obtained as $1125 \mathrm{GWh}$. Downdraft gasification technology can provide higher potential of energy generation.

\section{CONCLUSION}

Gasification is a proven technology route for conversion of biomass into hydrogen and other combustible products. The gasifier configurations have high influence on the product gas composition. This study evaluated the impact of different gasifiers on energy generation from forestry residues in Mediterranean Region of Turkey based on the previously published experimental data. Comparisons have proved that downdraft gasifier has higher energy production capacity than those of updraft and circulating fluidized bed systems. Mediterranean Region has shown to have $1125 \mathrm{GWh}$ annual thermal energy production potential from downdraft airgasification of forestry residues.

\section{ACKNOWLEDGEMENT}

The authors would like to thank Pak-Turk Researchers' Mobility Grant Program.

\section{REFERENCES}

[1] T.M.L. Winley, "The Paris warming targets: emissions requirements and sea level consequences", Climatic Change, vol. 147, 31-45, 2018.

[2] M. Richter, “Utilities' Business Models for Renewable Energy: A Review", Renewable and Sustainable Energy Reviews, vol. 16, no. 5, 2483-493, 2012. 
[3] Z. Akyürek, A.Ö. Akyüz, A. Güngör, "Optimizing the Tilt Angle of Solar Panels to Reduce Carbon Footprint: Case for the West Mediterranean Region of Turkey", International Journal of Engineering, Design and Technology, vol. 1, no. 1, 10-15, 2019.

[4] A. Hegazy, A.O. Ghallab, F.H. Ashour, "Integrated gasification combined cycle using Egyptian Maghara coalrice straw feedstock", Waste Management and Research, vol. 35, 656-68, 2017.

[5] A. Vakais, A. Sotiropoulos, K. Moustakas, D. Malamis, M. Baratieri, "Utilisation of biomass gasification by-products for onsite energy production", Waste Management \& Research, vol. 34, 564-71, 2017.

[6] G. Wielgosiński, P. Łechtańska, O. Namiecińska, O. "Emission of some pollutants from biomass combustion in comparison to hard coal combustion", Journal of the Energy Institute, vol. 90, 787-96, 2017.

[7] Z. Akyürek, A.Ö. Akyüz, A. Güngör, "Energy potential from gasification of agricultural residues in Burdur, Turkey", Techno-Science, vol. 2, no. 1, 15-19, 2019.

[8] Z. Akyürek, "Potential of biogas energy from animal waste in the Mediterranean Region of Turkey", Journal of Energy Systems, vol. 2, no. 4, 159-167, 2018.

[9] O. Gohlke, "Efficiency of energy recovery from municipal solid waste and the resultant effect on the greenhouse gas balance", Waste Management and Research, vol. 27, 894- 906, 2009.

[10] E.J. Lopes, , N. Queiroz, C.I.. Yamamoto, P.R.C. Neto, "Evaluating the emissions from the gasification processing of municipal solid waste followed by combustion", Waste Management, vol. 73, 504-10, 2018.

[11] K.G. Burra, M.S. Hussein, R.S., Amano, A.K. Gupta, "Syngas evolutionary behavior during chicken manure pyrolysis and air gasification", Applied Energy, vol. 181, 408-15, 2016.

[12] A. Gungor, M., Ozbayoglu, C. Kasnakoglu, A. Biyikoglu, B.Z. Uysal, "A parametric study on coal gasification for the production of syngas", Chemical Papers, vol 66, 677-683, 2012.

[13] A. Gungor, U. Yildirim, "Two dimensional numerical computation of a circulating fluidized bed biomass gasifier", Computers \& Chemical Engineering, vol 48, 234-50, 2013.

[14] S.K., Sansaniwal, K. Pal, M.A.. Rosen, S.K. Tyagi, "Recent advances in the development of biomass gasification technology: A comprehensive review", Renewable and Sustainable Energy Reviews, vol. 72, 36384, 2017.

[15] M. La Villetta, M., Costa, N. Massarotti, "Modelling approaches to biomass gasification: A review with emphasis on the stoichiometric method", Renewable and Sustainable Energy Reviews, vol 74, 71-88, 2017.

[16] R.C. Saxena, D. Seal, S Kumar, H.B. Goyal, "Thermo-chemical routes for hydrogen rich gas from biomass: a review", Renewable Sustainable Energy Reviews, vol 12, 1909-27, 2008.

[17] D. Sutton, B. Kelleher, J.R.H. Ross, "Review of literature on catalysts for biomass gasification", Fuel Process Technology, vol 73, 155-73, 2001.

[18] Y. Chhiti, M. Kemiha, "Thermal conversion of biomass, pyrolysis and gasification: a review", International Journal of Engineering Science, vol 2, 75-85, 2013.

[19] N. Couto, A. Rouba, V. Silva, E. Monteiro, K. Bouziane, "Influence of the biomass gasification processes on the final composition of syngas", Energy Procedia, vol 36, 596-606, 2013.

[20] N. Salami, Z. Skála, "Use of the Steam as Gasifying Agent in Fluidized Bed Gasifier", Chemical and Biochemical Engineering Quarterly, vol. 29, 13-18, 2015.

[21] BEPA, Biomass Atlas of Turkey, 2019. http://bepa.yegm.gov.tr/ (Accessed 22.07.2020)

[22] Hanaoka, T., Seiichi, I.S., Ogi, T., Uno, S., Minowa, T. "Effect of woody biomass components on air-steam gasification", Biomass and Bioenergy, vol. 28, 69-76, 2005. [23] Kim, Y.D., Yang, C.W., Kim, B.J., Kim, K.S., Lee, J.W., Moon, J.H., Yang, W., Yu, T.U., Lee, U.D., "Airblown gasification of woody biomass in a bubbling fluidized bed gasifier", Applied Energy, vol. 112, 414-420, 2013.

[24] Safarian, S., Unnthorsson R., Richter, C., Performance analysis of power generation by wood and woody biomass gasification in a downdraft gasifier, International Journal of Applied Power Engineering, vol. 10(1), 80-88, 2021.

[25] Republic of Turkey, Ministry of Agriculture and Forestry, General Directorate of Forestry. https://www.ogm.gov.tr/Sayfalar/Ormanlarimiz/lllere-

Gore-Orman-Varligi.aspx (Accessed 22.07.2020)

[26] S.K. Sansaniwala, M.A. Rosen, S.K. Tyagi, "Global challenges in the sustainable development of biomass gasification: An overview", Renewable and Sustainable Energy Reviews, vol 80, 23-43, 2017. 